\title{
Ecological study of Ghodaghodi lake
}

\author{
J. Diwakar ${ }^{1}$, S. Bajracharya ${ }^{1}$ and U.R. Yadav $^{1}$
}

\begin{abstract}
Wetlands comprise $5 \%$ of world's total land areas of Nepal. The present study Ghodaghodi Lake in the Far-West Nepal Terai manifested the physicochemical contamination in the lake. All the parameters were within the WHO guideline values except for Phosphate and Dissolved Oxygen. Water depth varies form 1-4 m. High phosphate level suggested that the lake is hypertrophic. Dissolved oxygen was low, ranging between $5.27-6.56 \mathrm{mg} / \mathrm{l}$. The presence of high density of Hemiptera (384.23 ind $\left./ \mathrm{m}^{2}\right)$ and Ephimeripterae (273.66 ind/ $\mathrm{m}^{2}$ ) indicted that water was polluted due to high nutrient deposition both from the decaying of the abundant aquatic flora and from the surrounding area. The most important challenge that we have to face is to strike a balance between sustainable human exploitation and maintaining the ecological character of a wetland ecosystem.
\end{abstract}

Key words: Ghodaghodi Lake, phytoplankton, macroinvertebrates, phosphate, nitrate

W etlands are lands transitional between terrestrial and aquatic systems where soil is frequently waterlogged, the water table is usually at or near the surface or the land is covered by shallow water. Entire civilization developed around wetland-areas of immense value both economically and in terms of quality life. But over exploitation of wetlands impairs its sustainability. Survival of human civilization in inextricably linked with wetlands. By sustaining the economic stability of hundreds of millions of people, the society is benefited from the wetlands in a different manner. On a shorter time scale, wetlands are usually useful as sources, sinks and transformers of a multitude of chemical, biological and genetic materials. They have been found to cleanse polluted water, prevent floods and recharge groundwater aquifers. Furthermore, wetlands provide a unique habitat for a wide variety of flora and fauna. James (1995) has rightly called the wetlands as nature's kidneys because of the natural functions they perform (Poddar et al 2001).

Water, the most vital resource for all life on this planet is also the resource, adversely affected qualitatively and quantitatively by different of human activities on land, in air, or in water. Today most of the surface and the ground water of the world receive millions of liters of sewage, domestic waste, industrial and agricultural effluents containing substances varying in characteristics from simple nutrients to highly toxic substances (Trivedy and Goel 1986).

Ghodaghodi lake is a natural freshwater oxbow lake on the lower slope of Siwalik. It is a large and shallow lake, having finger-like projections, with associated marshes and meadows surrounded by tropical deciduous forest on the lower slopes of Siwalik range. There are thirteen associated lakes and ponds; some streams have separated lakes and ponds, and some streams are separated by hillocks situated on the periphery of Ghodaghodi. The forest and wetland is a wildlife corridor between the low land and the Siwalik. The lake is fed by surface flows from the watershed area, groundwater, springs and small streams. Water depth varies from 1-4 m (DNPWC \& WWF 2005).

Site description: It is situated at an altitude of 205 metres above the sea level. Its latitude and longitude are $28^{\circ} 42^{\prime} 06.6^{\prime \prime} \mathrm{N}$ and $80^{\circ} 56^{\prime} 44^{\prime \prime} \mathrm{E}$ respectively. It is situated in Sukhad, ward no. 5, Darakh VDC, $1 \mathrm{~km}$ west of Sukhad Chouraha, Kailali district in the Terai region of Far-Western Development Region, Nepal. It lies along the Mahendra Highway (100 m north of the East-West highway) with several ramifications caused by soil erosion and running water. The lake is owned by the State and surrounded by national forest. Ghodaghodi lake is one of four Ramsar wetland sites of international importance in Nepal, and is part of the Terai Arc Landscape. Ghodaghodi lake (150 ha) is one of the 14 lakes of Ghodaghodi Lake Complex (2563 ha) - a Ramsar site of Nepal (Kafle 2006). Many of the branches become disconnected from the main water body during low water seasons. The wetland has a permanent flow. Recently, the temple of Ghodaghodi Deity has been built with the assistance from the local people and District

\footnotetext{
${ }^{1}$ Central Department of Environmental Science, Tribhuvan University, Kirtipur, P.O. Box: 9135, Kathmandu, Nepal

E-mail: jasdiwa@gmail.com
} 
Development Committee. The topography of the Lake is palm shaped with many ramifications. Among them, notches extending towards north are larger than those on other sides. The temperature rise is highest in the month of May, and drops to its lowest in the month of January. The mean maximum temperature of May was $37.2^{\circ} \mathrm{C}$ while in 1995 it reached the highest to $40.4^{\circ} \mathrm{C}$. Similarly, the mean minimum temperature of January was $7.54^{\circ} \mathrm{C}$; the lowest recorded temperature in 19 years was $7^{\circ} \mathrm{C}$ in December 1994. Pre-monsoon was the hottest season (average $34.43^{\circ} \mathrm{C}$ ) while the winter season was the coldest season (average $8.42^{\circ} \mathrm{C}$ ). The area receives an average annual rainfall of $1794.12 \mathrm{~mm}$. Dry and surplus year were almost similarly distributed (11:8) but of the total rainfall, $87.71 \%$ of rainfall occurred in monsoon season (June- September). This might be the reason for devastating flood in the monsoon season and dryness in the remaining seasons.

The lake supports critically endangered Red-crowned Roofed Turtle (Kachuga Kachuga); endangered Tiger (Panthera tigris), Three-striped Roof Turtle (Kachuga dhongka); vulnerable Smooth-coated Otter (Lutra perpiscillata), Common Otter (Lutra lutra), Swamp deer (Cervus duvaucelli), Lesser Adjutant Stork(Leptotilos javanicus) and Marsh Crocodile (Crocodylus palustris); and endangered Orchid (Aerides odorata), religiously important and threatened Lotus (Nelumbo nucifera), and rare wild rice (Hygrohiza aristata) (DNPWC \& WWF, 2005).

The lake is rich in floral diversity with excellent environment conditions for both lake and terrestrial (grassland and forest) vegetation. Lake vegetation includes the free floating species (Azolla, Lemna, Spirodela and Ricclocarpus), the submergent species (Hydrilla verticillata, Chara fragilis, Nitella spp and Potamogeton sp.) the rooted floating species (Leudwigia adscendens, Potamogeton natans, Nymphaeae stellata, Nymphoides sp. and Dictyospperum scaberrimum), the emergent species (Limnopbila indica and Monochoria hastata) and marshland species (Rannunculus, Phragmites phalaris, Oryza isachne, Shcoenoplectus, Ipomoea).

The wetland and surrounding forests are renowned for their rich mammalian fauna too. The lake is a wintering area for sizeable numbers of several species of waterfowl, and provides a staging area for many species during their migration.

The lake is also rich in herpetofauna and fishes. The lake area is a habitat for protected wildlife on Nepal such as the Marsh mugger, Endangered Golden monitor lizard, Indian python and tortoise. The lake area housed Common otter and indigenous species of fish. A large species of tortoise is also reported to be present in this area.

About 140 species of birds, both migrant and resident, representing over $16 \%$ of national avifauna have been reported in the area. A few birds that breed in north Asia are also reported to reside here. But the destruction and deterioration of the surrounding forest area have threatened their presence. It is the largest inter-connected natural lake system in the Terai of Nepal. The other lakes connected with it are Nakhrodi Lake, Baishhawa Lake, Ojhuwa Lake, Chidiya Lake, Budhi Nakhrodi Lake, Sunpokhari Lake and Ramphal Lake. It is vulnerable and is exposed to tremendous anthropogenic activities. Because of this the Lake has always been in the top priority of IUCN Nepal's Wetlands and Heritage Unit. Likewise, the Nepal Government has also listed it as a critical wetland habitat. Due to these reasons, Ghodaghodi Lake along with other lakes at its catchment area was selected as the site for the study.

\section{Materials and methods}

Physicochemical and the status of aquatic flora and fauna was determined for the assessment of water

Table 1: Test parameters, methods of analyses and instruments used

\begin{tabular}{clcl}
\hline S.N. & \multicolumn{1}{c}{ Parameters } & Unit & \multicolumn{1}{c}{ Method of analyses } \\
\hline 1 & $\mathrm{pH}$ & - & $\mathrm{pH}$ meter \\
2 & Temperature & ${ }^{0} \mathrm{C}$ & Mercuric thermometer \\
3 & Conductivity & $\mu \mathrm{s} / \mathrm{cm}$ & Conductivity meter \\
4 & Dissolved Oxygen & $\mathrm{mg} / \mathrm{L}$ & Winkler's Iodometric method \\
5 & Total Alkalinity & $\mathrm{mg} / \mathrm{L}$ & Titrimetric method \\
6 & Hardness & $\mathrm{mg} / \mathrm{L}$ & EDTA titrimetric method \\
7 & Chloride & $\mathrm{mg} / \mathrm{L}$ & Argentometric method \\
8 & Free Carbondioxide & $\mathrm{mg} / \mathrm{L}$ & Titrimetric method \\
9 & Nitrate-Nitrogen & $\mathrm{mg} / \mathrm{L}$ & Phenol Disulphonic acid method \\
10 & Phosphate & $\mathrm{mg} / \mathrm{L}$ & Ammonium molybdate method \\
\hline
\end{tabular}


quality of the lake. Analyses of the physico-chemical parameters were done by following APHA (1998). $\mathrm{pH}$ and Conductivity of water samples were recorded at the site during the sampling period. Other parameters were analyzed in the Environment Laboratory of CDES. The samples were analyzed on the same day immediately and always within 6 hours of collection. Test parameters, methods of analyses and instruments used for analyses are shown in Table 1.

Sampling of benthic fauna from different sites were carried out using the grab sampler of an area 0.02498 $\mathrm{m}^{2}$. During the collection of samples, grab sampler was locked initially and slowly dropped into the pond tying it with nylon thread, as the sampler touched the bottom it automatically unlocked itself grabbing the sediment within it. The sampler was pulled up and sediments were transferred into a bucket. To remove clay and organic matter, the sediments were sieved using sieve size number 106 micron. Then the sieved samples were stored in labelled polythene sample bag along with little water and carried back to the laboratory at CDES. The sorting of samples were carried out in white enamel trays with the help of forceps, brushes, and dropper.

\section{Results and discussion}

The temperature at various depths shows that the temperature gradually decreases with depths. The surface temperature at different sites ranged from $15^{\circ} \mathrm{C}$ to $16^{\circ} \mathrm{C}$, temperature at $1.5 \mathrm{~m}$ depth was $15^{\circ} \mathrm{C}$ at site 2 , and temperature at $1 \mathrm{~m}$ depth was $16^{\circ} \mathrm{C}$ at

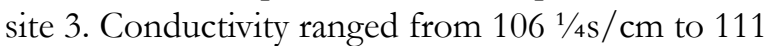
$1 / 4 \mathrm{~s} / \mathrm{cm}$. pH ranged from 6.9 to 7.4 . Dissolved Oxygen (DO) increased with depth. DO of surface water ranged from $5.27 \mathrm{mg} / 1$ to $5.43 \mathrm{mg} / \mathrm{l}$. DO of site 2 was $6.40 \mathrm{mg} / 1$ at $1 \mathrm{~m}$ depth and DO of site 3 was 6.56 at $1.5 \mathrm{~m}$ depth.. Total alkalinity ranged from $75 \mathrm{mg} / \mathrm{l}$ to $80 \mathrm{mg} / \mathrm{l}$ on the surface, $75 \mathrm{mg} / \mathrm{l}$ at $1.5 \mathrm{~m}$ depth of site 2 , and $75 \mathrm{mg} / 1$ at $1 \mathrm{~m}$ depth at site 3 .

Table 2: Physico-Chemical Parameters of Ghodaghodi Lake.

\begin{tabular}{|c|c|c|c|c|c|c|c|c|c|c|c|c|c|c|c|c|c|c|}
\hline \multirow{2}{*}{\multicolumn{7}{|c|}{ Parameters }} & \multirow{2}{*}{\multicolumn{3}{|c|}{$\begin{array}{c}\text { Site } 1 \\
\text { Surface }\end{array}$}} & \multicolumn{4}{|c|}{ Site 2} & \multicolumn{3}{|c|}{ Site 3} & & \\
\hline & & & & & & & & & & Surf & & & $5 \mathrm{~m}$ & Surf & face & $1 \mathrm{~m}$ & & \\
\hline \multicolumn{7}{|l|}{ Time } & \multicolumn{3}{|c|}{ 10:30 A.M } & \multicolumn{4}{|c|}{ 10:55 A.M } & \multicolumn{3}{|c|}{ 11:30 A.M } & & \\
\hline \multicolumn{7}{|c|}{ Air Temperature $\left({ }^{0} \mathrm{C}\right)$} & \multicolumn{3}{|c|}{18} & \multicolumn{4}{|c|}{17} & \multicolumn{3}{|c|}{17.5} & & \\
\hline \multicolumn{7}{|c|}{ Water Temperature $\left({ }^{\circ} \mathrm{C}\right)$} & \multicolumn{3}{|l|}{15} & \multicolumn{2}{|l|}{15.5} & \multicolumn{2}{|l|}{15} & \multicolumn{2}{|l|}{16} & \multicolumn{3}{|l|}{15} \\
\hline \multicolumn{7}{|c|}{ Conductivity $(\mu \mathrm{S} / \mathrm{cm})$} & \multicolumn{3}{|c|}{111} & \multicolumn{2}{|l|}{111} & \multicolumn{2}{|c|}{110} & \multicolumn{2}{|l|}{106} & 108 & & \\
\hline $\mathrm{pH}$ & & & & & & & 7.4 & & & 7.0 & & 7.2 & & 7.3 & & 6.9 & & \\
\hline Dissolved Ox & ygen & $(\mathrm{m}$ & $g /$ & & & & 5.35 & & & 5.43 & & 6.5 & & 5.27 & & 6.4 & & \\
\hline Phenolphthal & ein $A$ & Alk & lin & $(\mathrm{n}$ & & & 0 & & & 0 & & 0 & & 0 & & 0 & & \\
\hline Total Alkalini & ty $(\mathrm{m}$ & $\mathrm{ng} /$ & & & & & 80 & & & 80 & & 75 & & 75 & & 90 & & \\
\hline Hardness (mg & $/ 1)$ & & & & & & 52 & & & 51.2 & & 51. & & 58 & & 58 & & \\
\hline Chloride (mg, & & & & & & & 12.7 & & & 15.62 & & 13. & & 17.81 & & 17.04 & & \\
\hline Free Carbond & ioxic & de & $\mathrm{mg}$ & & & & 13.2 & & & 8.36 & & 12. & & 14.08 & & 15.4 & & \\
\hline Phosphate (m & $g / l)$ & & & & & & 0.40 & & & 0.105 & & 0.0 & & 0.421 & & 0.206 & & \\
\hline & & & & & & of in & ividua & (X) & & & & & & & & & & \\
\hline Name of species & & Site & & & & & Site 3 & & & Site 4 & & $\Sigma X_{1}$ & $\Sigma \mathrm{X}_{2}$ & Mean & Mean & Density & Density & $\begin{array}{l}\text { Average } \\
\text { Density }\end{array}$ \\
\hline & $\mathrm{A}$ & $\mathrm{B}$ & $\mathrm{C}$ & $\mathrm{A}$ & $\mathrm{B}$ & $\mathrm{A}$ & $\mathrm{B}$ & $\mathrm{C}$ & A & $\mathrm{B}$ & $\mathrm{C}$ & & & & & & & \\
\hline Gossiphonidae & 1 & - & - & - & - & - & - & - & - & - & - & 1 & 0 & 1 & 0 & 44.8 & - & 22.4 \\
\hline Hemiptera & 17 & 4 & 1 & 2 & 2 & 1 & 2 & - & - & - & - & 17 & 12 & 17 & 1.2 & 761.6 & 6.86 & 384.23 \\
\hline Linmea & 2 & 1 & - & - & - & - & - & - & - & - & - & 2 & 1 & 2 & 0.1 & 89.6 & 0.57 & 45.09 \\
\hline Diptera & 3 & - & 1 & - & - & - & - & - & - & - & - & 3 & 1 & 3 & 0.1 & 134.4 & 0.57 & 67.49 \\
\hline Ephimeripterae & 12 & 3 & 7 & - & - & 1 & - & - & - & 5 & 1 & 12 & 17 & 12 & 1.7 & 537.6 & 9.71 & 273.66 \\
\hline Chronomidae & 5 & 1 & 7 & - & - & 2 & 1 & 23 & 1 & 5 & 1 & 5 & 41 & 5 & 4.1 & 44.8 & 23.43 & 123.72 \\
\hline Mosquito larvae & 1 & - & - & - & - & - & - & - & - & - & - & 1 & 0 & 1 & 0 & - & - & 22.4 \\
\hline Gyraulus & - & - & 3 & - & 4 & 1 & - & 4 & - & 2 & 1 & - & 15 & - & 1.5 & - & 8.57 & 4.28 \\
\hline Hydracarina & - & 1 & - & - & - & 1 & - & - & - & - & - & - & 2 & - & 0.2 & - & 1.14 & 0.57 \\
\hline Dragonfly & - & 1 & - & - & - & - & - & - & - & - & - & - & 2 & - & 0.2 & - & 1.14 & 0.57 \\
\hline Ceratopogonidae & - & 1 & - & - & - & - & - & - & - & - & - & - & 1 & - & 0.1 & - & 0.57 & 0.29 \\
\hline Neritidae & - & - & 1 & - & - & - & - & - & - & - & 1 & - & 2 & - & 0.2 & - & 1.14 & 0.57 \\
\hline Segnentina & - & - & - & - & 3 & - & - & - & - & - & - & - & 3 & - & 0.3 & - & 1.71 & 0.86 \\
\hline Bithinidae & - & - & - & - & - & - & - & 1 & - & - & - & - & 1 & - & 0.1 & - & 0.57 & 0.29 \\
\hline Corixa & - & - & - & - & - & - & - & 1 & - & - & - & - & 1 & - & 0.1 & - & 0.57 & 0.29 \\
\hline Isopteron isopteran & - & - & - & - & - & - & - & - & - & - & 1 & - & 1 & - & 0.1 & - & 0.57 & 0.29 \\
\hline
\end{tabular}


Hardness ranged form $51.2 \mathrm{mg} / 1$ to $58 \mathrm{mg} / \mathrm{l}$ on the suface, $51.4 \mathrm{mg} / \mathrm{l}$ at site 2 and $58 \mathrm{mg} / 1$ at site 3 . Free carbondioxide ranged from $8.36 \mathrm{mg} / 1$ to $14.08 \mathrm{mg} /$ lon the surface, $12.32 \mathrm{mg} / \mathrm{l}$ at site 2 and $15.4 \mathrm{mg} / \mathrm{l}$ at site 3. Phosphate ranged from $0.409 \mathrm{mg} / 1$ to 0.421 $\mathrm{mg} / \mathrm{l}$ on the surface, $0.099 \mathrm{mg} / \mathrm{l}$ at site 2 and 0.206 $\mathrm{mg} / \mathrm{l}$ at site 3 . Its concentration decreased with depth. Regarding macroinvertebrates, higher density of Hemiptera (384.23 no. $/ \mathrm{m}^{2}$ ) and the least density of Isopteron isoptera, Corix, Bithindae and Ceratopogonidae (0.285 no. $/ \mathrm{m}^{2}$ each).

Wetlands are full of mystery. These forgotten places are some of our beautiful heritages. Nepal abounds in wetlands and has for centuries benefited form the wealth they have provided, timbers, fruits, firewood, fish and medicines. Our wetland wealth has become even more valuable in the face of increasing development pressures. Each year, uncontrolled development has been destroying scores of hectares of wetlands, the essential natural filters.

Pollution of water is responsible for a large number of mortalities and morbidities in the world. Water no longer remains a "free good." Man has tried to cope up with this scenario and has rapidly advanced its efforts to counterpart this malady. Over the past few decades, natural and polluted waters have been studied in detail all over the world and considerable data are now available on most kinds of pollutants and their effects on ecosystems as well as organisms. A regular monitoring of some of them not only prevents diseases and hazards but also checks the water resources from getting further polluted (Trivedy and Goel, 1986).

Temperature is an important limiting factor of an aquatic ecosystem and a good indicator of water quality. All metabolic and physiological activities such as respiration, circulation, and reproduction. are generally influenced by temperature. During the present investigation the temperature of surface water ranged form $15^{\circ} \mathrm{C}$ to $16^{\circ} \mathrm{C}$. The present investigation did not show considerable changes in temperature. The depth-wise analysis of temperature showed that there was a decrease in the temperature as the depth increases. It might be due to high density of phytoplankton at the upper layers, which restricts the solar radiation to penetrate into the deeper layers. One of the most unusual properties of water is the fact that its density does not monotonically increase as the temperature drops. Instead it has a maximum density at $4^{0} \mathrm{C}$. One result of this maximum density is that above $4^{\circ} \mathrm{C}$, the density of water decreases with temperature.

Dissolved oxygen is considered as an important parameter in water quality assessment. The concentration of oxygen in water depends mainly on two sources: diffusion from atmosphere, which depends on solubility of oxygen under the influence of temperature, salinity, water movement. and photosynthetic evolution, which is a biological process and depends on the availability of light and rate of metabolic process. The surface DO of all three sites is greater than $5 \mathrm{mg} / \mathrm{l}$ while the depth wise analysis of DO showed the increase in DO. This might be due to decrease in temperature with depth that causes decrease in the metabolic activities. Organisms have specific requirement for DO, so the lower concentration may affect the survival of aquatic organisms. The present study revealed that the values for DO in sample water from surface and depth wise analysis were above the WHO permissible value of $5 \mathrm{mg} / 1$.

The hardness of water is not actually a pollution parameter but indicates water quality. It is due to presence of dissolved salts of Calcium and Magnesium. It is expressed as an equivalent concentration of calcium carbonate in $\mathrm{mg} / \mathrm{l}$. Hard water requires a considerable amount of soap to produce lather. Scaling of hot water pipes, boilers and other household appliances is also due to the hard water. It was high at site 3 while least at site 2 , this might be due to presence of agricultural land in site 3 , which was more prone to pollution.

Carbon is usually found from a number of natural sources, including alkalinity, dissolved carbon dioxide from the atmosphere, and decaying organic matter. So, it is not often a limiting nutrient. The carbon dioxide in water increased with depth; this might be due to decomposition of dead and decayed parts of plants and other organisms.

The conductivity is a numerical expression of the ability of an aqueous solution to carry an electric current and depends on the presence of ions, their total concentration, mobility, valence and relative concentration and on the temperature measurement. It is an important criterion in determining the suitability of water for irrigation. Since the values of conductivity in all the sites exceeded the limiting value, the water was suitable for irrigation. 
There is no substantial alteration in the value of $\mathrm{pH}$ in different sites. The $\mathrm{pHs}$ at all the sites were within the specified range of water quality as prescribed by WHO guidelines 6.5-7.5.

In natural fresh water high concentration of chloride is considered to be an indicator of environment pollution due to organic wastage of animal origin. The maximum permissible WHO standard of chloride for drinking water is $250 \mathrm{mg} / \mathrm{l}$. The chloride concentrations at all the sites were within the specified range of water quality.

Alkalinity is the acid neutralizing capacity of water. In nature, due to the action of limestone in groundwater there occurs carbonates, bicarbonates, borate, silicates, and phosphates together with hydroxyl ions that contributes to alkalinity. The study revealed that phenolphthalein alkalinity was absent manifesting that the total alkalinity was only due to bicarbonates.

Phosphorus occurs in water mostly as phosphate. It is rarely found in high concentration at it is actively taken up by plants. Natural source of phosphorus are mainly due to the weathering of phosphorus bearing rocks and the decomposition of organic matter. In most natural surface water, phosphorus ranges from $0.0055-0.020 \mathrm{mg} / \mathrm{l}$ as ortho phosphate. In the study, all the sites have exceeded this natural level. The deviation to some extent might be due to agricultural runoff from the surrounding area.

Transparency of water denotes the ability of light to pass through the water so that object situated at depth can be clearly seen. Transparency is very important physical parameter, which directly influence the productivity status of water body. The presence of suspended dissolved organic, inorganic material and turbidity of water diminishes the sechhi disc transparency status and is essential a function of the reflection of light and restricts the penetration of light in an aquatic environment. All lakes gradually accumulate silt and organic matter as they undergo a natural aging process known as eutrophication. A young lake is characterized by low nutrient content and low plant productivity. Such oligotrophic lakes gradually acquire nutrients from their drainage basins, which facilitates increased aquatic growth. Over time, the increased biological productivity causes the water to become murky with phytoplankton, while decaying organic matter contributes to the depletion of available DO. The lake becomes eutotrophic as the accumulating silt and organic debris cause the lake to become shallower and warmer, more plants take root along the shallow edges, and the lake slowly transforms into a marsh or bog, while such eutrophication is a natural process that may take thousands of years, it is possible to accelerate greatly the rate of change through human activities. Algal blooms die and decay, causing unsightly, odorous clumps of rotting debris along the shoreline and thick mats of dead organic matter in the lake. The decomposition of dead algae uses up available oxygen, resulting in the same sort of oxygen depletion problems. Among the first casualties are cold water fish, whose temperature sensitivity forces them to stay in the colder bottom waters of lake where the least amount of oxygen, but the toxicity of the water increases as hydrogen sulfide and metals, such as iron and manganese, which are normally tied up as precipitates in sediments, are dissolved and released into the lake.

The bottom fauna plays an important role in the overall biological productivity of the lake. They serve as food for most of the bottom feeding fishes and are the nutritional sources. A total of 16 taxas were recorded from the lake. The density of Hemiptera spp. (384.33 ind $/ \mathrm{m}^{2}$ ) was the highest and that of Corix sp., Bithindae and Isopteron isopteran sp. $\left(0.2 \mathrm{ind} / \mathrm{m}^{2}\right.$ each) was the lowest.

The aquatic flora collected and identified during the study period are Lidwigia agscendens, Nymphoids sp., Hydrilla sp., Ceratophyllum sp. Trapa sp., Potamogetom natans, Pistia sp. and Hygorbyza sp. Protection of these water sources and their effective sustainable management are all-critical strategies in maintaining and improving water quality.

\section{Conclusion}

The present study disclosed the physicochemical contamination in the lake. All the parameters were within the WHO guideline value except phosphate and dissolved oxygen. Water depth varies form 1-4 $\mathrm{m}$. High phosphate level indicates the lake is hypertrophic. Dissolved oxygen is low ranging between $5.27-6.56 \mathrm{mg} / \mathrm{l}$. The presence of high density of Hemiptera (384.23 ind $/ \mathrm{m}^{2}$ ) and Ephimeripterae $\left(273.66\right.$ ind $\left./ \mathrm{m}^{2}\right)$ indicted that water is polluted due to high nutrient deposition from decaying of aquatic flora which were abundant and from the surrounding area. 


\section{Acknowledgements}

Acknowledgements are due to Central Department of Environmental Science, Kirtipur for the laboratory facilities and instruments provided for this work. We would like to thank people around Ghodaghodi lake who helped us during water sampling in their localities.

\section{References}

APHA. 1998. Statistical Method for the Examination of Water and Waste Water, 20 ${ }^{\text {th }}$ edition, American Public Health Association, American Water Works Association and Water Environment Federation, United Book Press, Inc. Baltimore, Maryland, USA.

BPP. 1995. Biodiversity Assessment of Terai Wetlands, Biodiversity Profile Project, Publication No. 1, Department of National Parks and Wildlife Conservation, Kathmandu, Nepal.

CBS. 1995. Statistical Analysis of Nepal, HMG National Planning Commission Secretariat, Central Bureau of Statistics, Kathmandu, Nepal.

DNPWC and WWF. 2005. Fact Sheet Ghodaghodi Lake Area Kailali, Department of National Parks and Wildlife Conservation and World Wildlife Fund, Kathmandu, Nepal.

Diwakar, J. 2007. Environmental study of Ghodaghodi Lake, a field study report submitted to Central Department of Environmental Science, Kirtipur, Nepal.

ENPHO. 1997. Water Resource Monitoring Program for the Shivapuri Watershed by Assessing Water Quality (1 ${ }^{\text {st }}$ phase), Environment and Public Health Organization, Kathmandu, Nepal.
IUCN Nepal. 1998. The Ghodaghodi Tal Conservation Area: A Community centered Management Plan, Ghodaghodi Kshetra Samrakshan, NAHASON and IUCN Nepal.

James, E. J. 1995. Managing the wetlands and their watersheds. Yojana 39(182): 43-50.

Kafle, G. 2006. Avifauna and Vegetation of Ghodaghodi Lake (A Ramsar Site ) of Nepal, Nature Conservation.

Poddar, P., Puste, A. M. and Sengupta, K., 2001. Wetlands And Their Agronomic Utilization. Environment and Agriculture and Pollution in South Asia. In: Proceedings of the International Conference on Environment and Agriculture, November 1-3, 1998, Kathmandu. P.K.Jha, S. B. Baral, S. B. Karmacharya, H.D. Lekhak, P. Lacoul and C. B. Baniya, Eds. Ecological Society (ECOS), Kathmandu. 2: 410-413.

Toalanur, S. 2004. Practical Soil Science and Agricultural Chemistry, First edition, International Book Distributing Co., India.

Trivedy, R. K. and Goel, P. K. 1987. Chemical and Biological Method for Water Pollution Studies, $1^{\text {st }}$ edition, Environmental Publication, Karad, India.

WHO. 1971. International Standard for Drinking Water, World Health Organization.

Zobel, D. B., Yadav, U.K.R., Jha, P.K. and Behn, M. J. 1987. A Practical Manual for Ecology, Ratna Pustak Bhandar, Kathmandu, Nepal. 